\title{
Article \\ Chemical Composition and Synergistic Potential of Mentha pulegium L. and Artemisia herba alba Asso. Essential Oils and Antibiotic against Multi-Drug Resistant Bacteria
}

\author{
Fahima Bekka-Hadji ${ }^{1,2}$, Isabelle Bombarda ${ }^{3, *}$, Ferhat Djoudi ${ }^{2}$, Sofiane Bakour ${ }^{4}$ and Abdelaziz Touati $^{2}$ \\ 1 Département de Microbiologie Appliquée et Sciences Alimentaires, Faculté des Sciences de la Nature et de la \\ Vie, Université de Jijel, Jijel 18000, Algeria; fahima.bekka@hotmail.com \\ 2 Laboratoire d'Ecologie Microbienne, Faculté des Sciences de la Nature et de la Vie, Université de Bejaia, \\ Bejaia 06000, Algeria; djoudi.ferhat@gmail.com (F.D.); ziz1999@yahoo.fr (A.T.) \\ 3 Aix Marseille Univ, Université Avignon, CNRS, IRD, IMBE, 13013 Marseille, France \\ 4 Aix Marseille Univ, IRD, APHM, MEPHI, IHU-Méditerranée Infection, 13013 Marseille, France; \\ b.sofiane-microbio@hotmail.fr \\ * Correspondence: isabelle.bombarda@univ-amu.fr
}

check for updates

Citation: Bekka-Hadji, F.; Bombarda, I.; Djoudi, F.; Bakour, S.; Touati, A. Chemical Composition and Synergistic Potential of Mentha pulegium L. and Artemisia herba alba Asso. Essential Oils and Antibiotic against Multi-Drug Resistant Bacteria Molecules 2022, 27, 1095. https:/ / doi.org/10.3390/molecules27031095

Academic Editor: Luca Valgimigli

Received: 29 December 2021

Accepted: 2 February 2022

Published: 7 February 2022

Publisher's Note: MDPI stays neutral with regard to jurisdictional claims in published maps and institutional affiliations.

Copyright: (C) 2022 by the authors. Licensee MDPI, Basel, Switzerland. This article is an open access article distributed under the terms and conditions of the Creative Commons Attribution (CC BY) license (https:// creativecommons.org/licenses/by/ $4.0 /)$.

\begin{abstract}
The essential oils were obtained by hydrodistillation from aerial parts of Mentha pulegium L. (M. pulegium L.) and Artemisia herba alba (A. herba alba) Asso. and analyzed by gas chromatographyflame ionization detector chromatograpy (GC-FID) and gaz chromatography-mass spectrometry (GC-MS). The antibacterial activities of the oils were determined by the disk diffusion method and a microdilution broth assay against six bacteria stains. The combinations of these essential oils with antibiotics were evaluated against two multi-drug-resistant bacteria strains: imipenem-resistant Acinetobacter baumannii (IRAB S3310) and methicillin-resistant Staphylococcus aureus (MRSA S19). The chemical analysis of M. pulegium essential oil revealed the presence of pulegone $(74.8 \%)$ and neoisomenthol (10.0\%). A. herba alba essential oil was characterized by camphor $(32.0 \%)$, $\alpha$-thujone $(13.7 \%), 1,8$-cineole $(9.8 \%)$, $\beta$-thujone (5.0\%), bornéol (3.8\%), camphene (3.6\%), and $p$-cymene $(2.1 \%)$. All strains tested except Pseudomonas aeruginosa were susceptible to these oils. The combinations of essential oils with antibiotics exerted synergism, antagonism, or indifferent effects. The best effect was observed with $A$. herba alba essential oil in association with cefoxitin (CX) against MRSA S19. However, for IRAB S3310, the strongest synergistic effect was observed with M. pulegium in association with amikacin (AK). This study demonstrated that M. pulegium and A. herba alba essential oils have antibacterial activities which could be potentiated by antibiotics especially in the case of IRAB S3310.
\end{abstract}

Keywords: essential oil; antibacterial activity; multi-drug-resistant bacteria; antibiotic; synergism

\section{Introduction}

Antibiotics are one of the most common drug groups used in human and veterinary medicine. However, the massive and sometimes inappropriate use of antibiotics contributes to the emergence of multi-resistant bacteria including methicillin-resistant Staphylococcus aureus (S. aureus; MRSA) and carbapenems-resistant Acinetobacter baumannii (CRAB), which are considered to be the most multi-resistant pathogens feared in nosocomial infections [1,2]. The resistance of $S$. aureus to antibiotics is common. The capacity to cause various infections and its adaptation ability are the main concerns about this highly virulent pathogen. In addition, infections due to the antibiotics-resistant acinetobacter, including imipenem (IMP), have emerged over the years, leading up to therapeutic impasses. The growing concern about drug resistance has led researchers to focus more attention on natural products, including plants, with antimicrobial properties as a promising source of antimicrobial agents [3]. The antimicrobial properties of essential oils (EOs) from a wide variety of 
aromatic plants have been assessed and reviewed and confirm their use in traditional medicine as well as to extend the shelf life of foods [4-8].

Studies have shown the antibacterial activity of EOs against multi-resistant Gramnegative bacteria including Escherichia coli (E. coli) resistant to nalixidic acid or Klebsielle pneumoniae, a $\beta$-lactamase-producing strain with a widened CTXM spectrum $[9,10]$ and Gram-positive bacteria, particularly against methicillin-resistant $S$. aureus [11-14]. The metabolite diversity of the oils confers a wide variety of biological properties, some of which constitute alternatives or supplements to synthetic compounds [15]. The synergistic effect obtained from a combination of antibiotics with plant extracts against resistant bacteria leads to new ways for the treatment of infectious diseases [16]. At the same time, most in vitro studies have focused on the combination of antibiotics and EOs to overcome the resistance problem $[15,17]$.

The Mentha genus is a member of the Labiatae family. Leaves, flowers and stems of Mentha sp. are frequently used in herbal teas or as additives in commercial spice mixtures for many foods to offer flavor. In addition, Mentha sp. is often used in folk medicine to treat various diseases such as nausea, bronchitis, and ulcerative colitis.

Mentha pulegium L. (M. pulegium L.) is one of the Mentha species commonly known as pennyroyal. This species is generally known under the name "Feliou". The chemical composition of M. pulegium EO has been subjected to several studies, which have shown differences in their constituents depending on the country and region of cultivation [18-20].

The genus Artemisia (more than 400 species) belongs to the Asteraceae family. It is common in the North and East Africa, but it also described in the Southern Hemisphere [21,22]. In Algeria, approximately 12 species are listed including Artemisia herba alba ( $A$. herba alba) called Echih in Arabic [18]. This species is used to treat ulcers, dyspepsia, liver disorders, mouth ulcers, fungal infections, insect bites and scorpion, and all forms of poisoning [22,23]. It enjoys a great popularity, probably based on its antiseptic, antispasmodic, and antitumor properties, and the EO of this species is used primarily in perfumery and cosmetics [22,23].

This study aimed to evaluate the chemical compositions and the antibacterial activities of these two EOs, M. pulegium L. and A. herba alba Asso., growing in Bejaia (Algeria) and largely used in Algerian folk medicine, against a large panel of Gram-positive and Gramnegative bacterial strains including two multi-drug bacteria (methicillin-resistant $S$. aureus and imipenem-resistant Acinetobacter baumannii). In a second step, the associative effects of these two EOs with different groups of antibiotics against MRSA and IRAB isolates were studied for the first time.

\section{Results and Discussion}

\subsection{EOs Chemical Compositions}

The EO of M. pulegium studied was characterized by high contents of pulegone $(74.8 \%)$ and menthol $(10.0 \%)$. The complete relative composition was published in our previous work [13]. The high level of pulegone was never put in evidence and was characteristic of this algerian sample from Bejaia.

The EO of $A$. herba alba studied in this work contained camphor as a main product (32.0\%), followed by $\alpha$-thujone (13.7\%), 1,8-cineole (9.8\%), $\beta$-thujone (5.0\%), borneol (3.8\%), camphene $(3.6 \%)$, and $p$-cymene $(2.1 \%)$ (Table 1$)$.

The study of a large number of samples from Maroc allowed [24] describing four chemotypes of which the differences mainly concern three ketones, $\alpha$ - and $\beta$-thuyone and camphor, representing between $60 \%$ and $80 \%$ of the total EO. The four chemotypes reported were $\alpha$-thuyone/camphor, camphor, $\alpha$-thuyone, and $\beta$-thuyone. Two other chemotypes including davanone and cis-chrysanthenyl acetate have also been identified [25]. Other chemotypes were reported from Algerian $A$. herba alba EOs including camphor, $\alpha$ thuyone / $\beta$-thuyone, 1,8-cineole, and chrysanthenyl derivatives [26-28]. From all these works, our sample of $A$. herba alba can be classified in the camphor chemotype. 
Table 1. Chemical composition of Artemisia herba alba (A. herba alba) essential oil growing wild in Bejaia (Algeria).

\begin{tabular}{|c|c|c|c|}
\hline $\mathbf{R I}^{\mathbf{a}}$ & $\mathrm{RI}^{\mathrm{b}}$ & Compounds & Relative Composition ${ }^{c}$ \\
\hline 913 & 924 & $\alpha$-thujene & 0.3 \\
\hline 924 & 932 & $\alpha$-pinene & 1.6 \\
\hline 945 & 946 & camphene & 3.6 \\
\hline 974 & 969 & sabinene & 0.3 \\
\hline 981 & 974 & $\beta$-pinene & 0.2 \\
\hline 990 & 988 & $\beta$-myrcene & 0.3 \\
\hline 1009 & 1002 & $\alpha$-phellandrene & 0.1 \\
\hline 1015 & 1008 & 3-carene & 0.2 \\
\hline 1020 & 1014 & $\alpha$-terpinene & 0.2 \\
\hline 1027 & 1020 & p-cymene & 2.1 \\
\hline 1030 & 1024 & limonene & 0.4 \\
\hline 1035 & 1026 & 1,8-cineole & 9.8 \\
\hline 1058 & 1054 & $\gamma$-terpinene & 0.7 \\
\hline 1068 & 1065 & cis-sabinene hydrate & 0.4 \\
\hline 1091 & 1083 & fenchone & 0.6 \\
\hline 1107 & 1101 & $\alpha$-thujone & 13.7 \\
\hline 1118 & 1112 & $\beta$-thujone & 5.0 \\
\hline 1128 & 1124 & chrysanthenone & 1.7 \\
\hline 1143 & 1139 & pinocarvéol & 1.2 \\
\hline 1151 & 1141 & camphor & 32.0 \\
\hline 1169 & 1167 & menthol & 1.0 \\
\hline 1172 & 1165 & borneol & 3.8 \\
\hline 1183 & 1174 & terpinen-4-ol & 0.9 \\
\hline 1191 & 1179 & p-cymen-8-ol & 0.2 \\
\hline 1205 & 1195 & myrtenal & 0.5 \\
\hline 1252 & 1239 & carvone & 0.2 \\
\hline 1296 & 1289 & thymol & 0.6 \\
\hline 1306 & 1298 & carvacrol & 1.7 \\
\hline 1331 & 1324 & myrtenyl acetate & 0.4 \\
\hline 1507 & 1500 & bicyclogermacrene & 0.2 \\
\hline 1532 & 1522 & $\delta$-cadinene & 0.1 \\
\hline 1564 & - & eudesma-3,7(11)-diene & 0.1 \\
\hline 1595 & 1582 & caryophyllene oxide & 0.2 \\
\hline 1615 & 1602 & ledol & 0.1 \\
\hline
\end{tabular}

a Retention indices relative to homologous $n$-alkanes C6-C26 obtained on an HP-5 capillary column. ${ }^{\mathrm{b}}$ Retention indices from the literature (Adam, 2007). ${ }^{\mathrm{C}}$ Experimental relative area percentage obtained by chromatography (GC) on an HP-5 capillary column.

\subsection{Antibacterial Activity}

The antibacterial activities of M. pulegium and A. herba alba EOs against several bacteria were examined in the present study. The data obtained were expressed by the diameters of the inhibition zones and the minimal inhibitory concentrations (MICs). The results are given in Table 2 (Figures S1 and S2).

The results showed that the EOs of the two species had great potential for antibacterial activities against all bacterial strains tested, except Pseudomonas aeruginosa (P. aeruginosa). The diameters of inhibition zones and MIC values for bacterial strains, which were sensitive to the EO of M. pulegium, varied from 17.8 to $25.3 \mathrm{~mm}$ and from 1.2 to $9.4 \mu \mathrm{L} / \mathrm{mL}$, respectively. For the $\mathrm{EO}$ of $A$. herba alba, the diameters of inhibition zones and MIC values varied from 13.2 to $19.7 \mathrm{~mm}$ and from 1.2 to $4.7 \mu \mathrm{L} / \mathrm{mL}$, respectively.

Several authors have reported activity for the EO of M. pulegium against S. aureus, Listeria monocytogenes strains, and other Gram-negatives bacteria, except P. aeruginisa [20,29]. The antibacterial activity of this EO might be due to the presence of pulegone, menthone, and neo-menthol [30]. Duru et al. [31] demonstrated that pulegone exhibits a high antimicrobial activity on the all-test bacteria, especially Salmonella typhimurium and S. aureus. 
Table 2. IZDs (mm) and MICs for Mentha pulegium L. (M. pulegium L.) and A. herba alba Asso. essential oils against bacteria strains.

\begin{tabular}{|c|c|c|c|c|c|c|c|}
\hline Plants & $\begin{array}{l}\text { Essential } \\
\text { Oil }\end{array}$ & $\begin{array}{c}\text { Staphylococcus } \\
\text { aureus } \\
\text { ATCC } 25923\end{array}$ & MRSA S19 & $\begin{array}{l}\text { Listeria } \\
\text { innocua } \\
\text { CLIP } 74915\end{array}$ & $\begin{array}{l}\text { Escherichia } \\
\text { coli } \\
\text { ATCC25922 }\end{array}$ & $\begin{array}{c}\text { Pseudomonas } \\
\text { aeruginosa } \\
\text { ATCC } 27853\end{array}$ & IRABS3310 \\
\hline \multirow{2}{*}{ M. pulegium L. } & IZD & $18.2 \pm 0.4$ & $17.8 \pm 2.9$ & $20.7 \pm 1.6$ & $17.2 \pm 0.7$ & $06.6 \pm 0.5$ & $25.3 \pm 3$ \\
\hline & MIC & 1.2 & 2.3 & 1.2 & 9.4 & 75 & 1.2 \\
\hline \multirow{2}{*}{ A. herba alba Asso. } & IZD & $19.7 \pm 0.7$ & $13.5 \pm 0.0$ & $13.2 \pm 0.9$ & $13.2 \pm 0.1$ & NZ & $15.3 \pm 0.6$ \\
\hline & MIC & 1.2 & 1.2 & 1.2 & 4.7 & 18.8 & 1.2 \\
\hline ciprofloxacin (CIP) & IZD & - & - & - & $34 \pm 2.8$ & $38.5 \pm 0.0$ & $14 \pm 0.0$ \\
\hline amikacin (AK) & IZD & - & - & - & $20 \pm 0.0$ & $26 \pm 0.0$ & $12 \pm 0.5$ \\
\hline oxacillin (OX) & IZD & $25.5 \pm 0.7$ & $19 \pm 0.0$ & - & - & - & - \\
\hline cefoxitin (CX) & IZD & $25.5 \pm 0.7$ & $19.5 \pm 0.0$ & - & - & - & - \\
\hline vancomycin (VAN) & IZD & $18.8 \pm 2.5$ & $17.5 \pm 0.0$ & - & - & - & - \\
\hline
\end{tabular}

IZD, the inhibition zone diameter $(\mathrm{mm})$ including the disc diameter of $6 \mathrm{~mm}$. The values are given as the mean \pm standard deviation; NZ, no inhibition zone; MIC, minimal inhibitory concentration in $\mu \mathrm{L} / \mathrm{mL}$.

The EO of $A$. herba alba tested in this study exhibited an interesting antibacterial activity against all strains except $P$. aeruginosa. The less sensitivity to $P$. aeruginosa strain was already observed for various chemotypes of $A$. herba alba [32].

Several authors report the low or even absence of the activity of EOs against P. aeruginosa [33,34]. The Iranian fresh oils of Thymus persicus L. and Thymus kotschyanus Boiss. were tested for their bacteriostatic and bactericidal effects at a dilution of $1 / 16$ against five bacterial stains. P. aeroginosa is not affected with inhibition zones ranging from 6 to $12 \mathrm{~mm}$ (disc diameter included). However, for the S. aureus strain, the inhibition zone obtained is $75 \mathrm{~mm}$ [35].

\subsection{Screening the Synergistic Effect of the EO with Antibiotic Discs}

In this work, the synergy was studied between EOs (M. pulegium L. and A. herba alba Asso.) and a set of antibiotics belonging to different groups. The associations were studied on two multiresistant strains: imipenem-resistant Acinetobacter baumannii (IRAB S3310), which is resistant to imipenem (IMP), cefotaxime (CTX), cefipime (FEP), and other antibiotics, as well as methicillin-resistant $S$. aureus (MRSA S19), which showed a resistance towards oxacillin (OX) and cefoxitin (CX).

The inhibitory effects of three antibiotics including OX, CX, and vancomycin (VAN) and the EOs of M. pulegium and A. herba alba against MRSA S19, alone and in combination, are presented in Tables 3 and 4 .

The values of the diameters of inhibition zones did not include the disc diameter $(6 \mathrm{~mm})$ in this part. A synergetic effect was observed for the two EOs and particularly in association with CX. The best effect was observed for the association of CX with $A$. herba alba EO against MRSA S19 (the inhibition zone diameter of the EO alone was $7.5 \mathrm{~mm}$, and that was $29.0 \mathrm{~mm}$ in association). According to Uzair et al. [36], the amoxicillin antibacterial activity against MRSA can be enhanced using active constituents present in the EOs of M. pulegium and A. herba alba used in traditional medicine has been reported to have a significant effect against the resistance of $S$. aureus when combined with chloramphenicol, gentamicin, and cephalexin [37]. D'Arrigo et al. [38] showed that the EO of Melaleuca alternifolia has a synergistic activity against $S$. aureus when combined with tobramycin (TOB). The combination of thymoquinone and thymohydroquinone with antibiotics (ampicillin, cephalexin, chloramphenicol, tetracycline, gentamicin, and ciprofloxacin (CIP)) exerts synergism in S. aureus. On the other hand, in Gram-negative bacteria, synergism, antagonism, and indifferent effects were detected [39]. 
Table 3. IZDs ${ }^{\text {a }}$ (mm) of M. pulegium essential oil and antibiotics, alone and in combination, against MRSA S19 and IRABS3310 bacteria.

\begin{tabular}{|c|c|c|c|c|c|c|c|}
\hline & Groups & Antibiotics & $\begin{array}{c}\text { Inhibition } \\
\text { Zone a with } \\
\text { the } \\
\text { Antibiotics }\end{array}$ & $\begin{array}{c}\text { Inhibition Zone } \\
{ }^{\text {a }} \text { with the } \\
\text { Essential Oil }\end{array}$ & $\begin{array}{l}\text { Sum of the } \\
\text { Inhibitions } \\
\text { Zone }{ }^{\text {a }} \text { with the } \\
\text { Antibiotics and } \\
\text { Essential Oil }\end{array}$ & $\begin{array}{l}\text { Inhibition Zone } \\
\text { with the } \\
\text { Antibiotics and } \\
\text { the Essential Oil } \\
\text { in Association }\end{array}$ & Effects ${ }^{b}$ \\
\hline \multirow{3}{*}{ MRSA S19 } & penicillin & OX & $13.0 \pm 0.0$ & $11.8 \pm 2.9$ & $>24.8$ & $19.4 \pm 1.5$ & A \\
\hline & cephalosporines & $\mathrm{CX}$ & $13.5 \pm 0.0$ & $11.8 \pm 2.9$ & $>25.3$ & $26.8 \pm 0.6$ & S \\
\hline & glycopeptids & VAN & $11.5 \pm 0.0$ & $11.8 \pm 2.9$ & $>23.3$ & $14.5 \pm 0.0$ & A \\
\hline \multirow{11}{*}{$\begin{array}{l}\text { IRAB } \\
\text { S3310 }\end{array}$} & \multirow{3}{*}{ penicillin } & TIC & $\mathrm{NZ}$ & $19.3 \pm 3$ & $>19.3$ & $16.1 \pm 1.0$ & A \\
\hline & & PIP & NZ & $19.3 \pm 3$ & $>19.3$ & $14.0 \pm 2.0$ & A \\
\hline & & TCC & $\mathrm{NZ}$ & $19.3 \pm 3$ & $>19.3$ & $27.5 \pm 1.3$ & $S$ \\
\hline & \multirow{3}{*}{ cephalosporines } & CTX & NZ & $19.3 \pm 3$ & $>19.3$ & $17.0 \pm 2.0$ & $\mathrm{~A}$ \\
\hline & & CAZ & NZ & $19.3 \pm 3$ & $>19.3$ & $22.7 \pm 1.5$ & $S$ \\
\hline & & FEP & $\mathrm{NZ}$ & $19.3 \pm 3$ & $>19.3$ & $24.5 \pm 0.9$ & $S$ \\
\hline & carbapenems & IMP & $\mathrm{NZ}$ & $19.3 \pm 3$ & $>19.3$ & $24.8 \pm 0.3$ & $S$ \\
\hline & \multirow{2}{*}{ aminoglycosides } & AK & $6.0 \pm 0.0$ & $19.3 \pm 3$ & $>25.3$ & $34.0 \pm 1.0$ & $S$ \\
\hline & & TOB & $9.0 \pm 0.0$ & $19.3 \pm 3$ & $>28.3$ & $29.0 \pm 3.0$ & $S$ \\
\hline & fluoroquinolones & $\begin{array}{l}\text { CIP } \\
\text { NA }\end{array}$ & $\begin{array}{c}8.0 \pm 0.0 \\
\mathrm{NZ}\end{array}$ & $\begin{array}{l}19.3 \pm 3 \\
19.3 \pm 3\end{array}$ & $\begin{array}{l}>27.3 \\
>19.3\end{array}$ & $\begin{array}{l}24.7 \pm 0.6 \\
18.5 \pm 1.3\end{array}$ & $\begin{array}{l}\mathrm{A} \\
\mathrm{A}\end{array}$ \\
\hline & monobactames & $\mathrm{AT}$ & $4.0 \pm 0.0$ & $19.3 \pm 3$ & $>23.3$ & $16.8 \pm 1.8$ & $\mathrm{~A}$ \\
\hline
\end{tabular}

${ }^{a}$ The inhibition zone non includes the diameter of the disc, and values are given as the mean \pm standard deviation; ${ }^{\mathrm{b}} \mathrm{A}$, antagonism; S, synergism; NZ, no inhibition zone; OX, oxacillin; CX, cefoxitin; Van, vancomycin; TIC, ticarcillin; PIP, piperacillin; TCC, ticarcillin-clavulanic acid; CTX, cefotaxime; CAZ, ceftazidime; FEP, cefepime; IMP, imipenem; AK, amikacin; TOB, tobramicin; CIP, ciprofloxacin; NA, nalidixic acid; AT, aztreonam.

The antibacterial activities against imipenem-resistant Acinetobacter baumannii (IRAB S3310) conducted on various groups of antibiotic including amikacin (AK), nalidixic acid (NA), aztreonam (AT), ceftazidime (CAZ), ciprofloxacin (CIP), cefotaxime (CTX), cefepime (FEP), imipenem (IMP), piperacillin (PIP), ticarcillin-clavulanic acid (TCC), ticarcillin (TIC), and tobramicin (TOB) and the EOs of M. pulegium and A. herba alba, alone and in combination, are presented on Tables 3 and 4 (and Figures S3 and S4). The combination of M. pulegium EO and different antibiotics showed antagonistic interactions with NA, AT, CIP, CTX, PIP, and TIC compared to the EO alone, while a synergistic effect was obtained with AK, CAZ, FEP, IMP, TCC, and TOB. The greatest effect was obtained for AK. In the case of $A$. herba alba, antagonistic interactions were observed for AK, AT, CIP, FEP, PIP, and TOB, while an indifferent effect was obtained with CAZ and TIC. Unlike the EO alone, synergistic effects were obtained with NA, CTX, IMP, and TCC, and the greatest effect was obtained for CTX.

The EO of M. pulegium had a better effect than the EO of A. herba alba. Strong synergistic effects were observed for M. pulegium $\mathrm{EO}$ in association with antibiotics belonging to penicillin, cephalosporin, carbapenems and aminoglycoside groups. In fact, the inhibition zone diameter increased from $19.3 \mathrm{~mm}$ for the oil alone to $27.5 \mathrm{~mm}$ for the EO/TCC combination and to $34 \mathrm{~mm}$ for the EO/AK combination. According to the results cited above, we found that the sensitivity of IRAB S3310 to the EOs/antibiotics combinations tested differed according to the EO and the antibiotic used in combination. The EO of M. pulegium was the most active in combination with the different antibiotics; the combination with antibiotics often gave a synergistic effect. However, the activity was less important for the $\mathrm{EO}$ of $A$. herba alba. 
Table 4. IZDs ${ }^{\text {a }}(\mathrm{mm})$ of $A$. herba alba essential oil and antibiotics, alone and in combination, against MRSA S19 and IRABS3310 bacteria.

\begin{tabular}{|c|c|c|c|c|c|c|c|}
\hline & roups & Antibiotics & $\begin{array}{l}\text { Inhibition } \\
\text { Zone }{ }^{\mathrm{a}} \text { with } \\
\text { the } \\
\text { Antibiotics }\end{array}$ & $\begin{array}{c}\text { Inhibition Zone } \\
\text { a with the } \\
\text { Essential Oil }\end{array}$ & $\begin{array}{l}\text { Sum of the } \\
\text { Inhibitions } \\
\text { Zone a with the } \\
\text { Antibiotics and } \\
\text { the Essential Oil }\end{array}$ & $\begin{array}{c}\text { Inhibition Zone } \\
\text { with the } \\
\text { Antibiotics and } \\
\text { the Essential Oil } \\
\text { in Association }\end{array}$ & Effects $^{b}$ \\
\hline \multirow{3}{*}{ MRSA S19 } & penicillin & OX & $13.0 \pm 0.0$ & $07.5 \pm 0.0$ & $>20.5$ & $20.8 \pm 0.6$ & I \\
\hline & cephalosporines & CX & $13.5 \pm 0.0$ & $07.5 \pm 0.0$ & $>21.0$ & $29.0 \pm 0.0$ & $\mathrm{~S}$ \\
\hline & glycopeptids & VAN & $11.5 \pm 0.0$ & $07.5 \pm 0.0$ & $>19.0$ & $17.7 \pm 0.3$ & A \\
\hline \multirow{11}{*}{ IRABS3310 } & \multirow{3}{*}{ penicillin } & TIC & NZ & $9.3 \pm 0.6$ & $>09.3$ & $09.6 \pm 2.1$ & I \\
\hline & & PIP & NZ & $9.3 \pm 0.6$ & $>09.3$ & $06.6 \pm 1.3$ & A \\
\hline & & TCC & NZ & $9.3 \pm 0.6$ & $>09.3$ & $10.5 \pm 0.5$ & S \\
\hline & \multirow{3}{*}{ cephalosporines } & CTX & NZ & $9.3 \pm 0.6$ & $>09.3$ & $13.3 \pm 2.6$ & S \\
\hline & & CAZ & NZ & $9.3 \pm 0.6$ & $>09.3$ & $09.6 \pm 2.1$ & I \\
\hline & & FEP & NZ & $9.3 \pm 0.6$ & $>09.3$ & $08.8 \pm 1.0$ & A \\
\hline & carbapenems & IMP & NZ & $9.3 \pm 0.6$ & $>09.3$ & $10.8 \pm 1.6$ & S \\
\hline & \multirow{2}{*}{ aminoglycosides } & $\mathrm{AK}$ & $6.0 \pm 0.0$ & $9.3 \pm 0.6$ & $>15.3$ & $13.0 \pm 2.6$ & A \\
\hline & & TOB & $9.0 \pm 0.0$ & $9.3 \pm 0.6$ & $>18.3$ & $17.0 \pm 2.0$ & A \\
\hline & fluoroquinolones & $\begin{array}{l}\text { CIP } \\
\text { NA }\end{array}$ & $\begin{array}{c}8.0 \pm 0.0 \\
\mathrm{NZ}\end{array}$ & $\begin{array}{l}9.3 \pm 0.6 \\
9.3 \pm 0.6\end{array}$ & $\begin{array}{l}>17.3 \\
>09.3\end{array}$ & $\begin{array}{l}15.3 \pm 1.0 \\
10.3 \pm 1.5\end{array}$ & $\begin{array}{l}\text { A } \\
\text { S }\end{array}$ \\
\hline & monobactames & AT & $4.0 \pm 0.0$ & $9.3 \pm 0.6$ & $>13.3$ & $09.5 \pm 3.3$ & A \\
\hline
\end{tabular}

a The inhibition zone non includes the diameter of the disk, and values are given as the mean \pm standard deviation; b A, antagonism; S, synergism; NZ, no inhibition zone; OX, oxacillin; CX, cefoxitin; VAN, vancomycin; TIC, ticarcillin; PIP, piperacillin; TCC, ticarcillin-clavulanic acid; CTX, cefotaxime; CAZ, ceftazidime; FEP, cefepime; IMP, imipenem; AK, amikacin; TOB, tobramicin; CIP, ciprofloxacin; NA, nalidixic acid; AT, aztreonam.

Rosato et al. [15] have underlined the strong synergy observed between gentamicin and Anibarosae odora against the Gram-negative A. baumannii. The combinations of coriander oil with chloramphenicol against $A$. baumannii have shown a synergistic effect. A synergistic, but less pronounced, behavior can be seen when combining coriander oil with either ciprofloxacin CIP, gentamicin, or tetracycline [17]. The study conducted by Boonyanugomol et al. [40] has shown that the EO of Zingiber cassumunar has a synergistic effect when combined with aminoglycosides, fluoroquinolones, and tetracyclines against the extensively drug-resistant $A$. baumannii strains.

The different activities observed for the EOs of M. pulegium and A. herba alba (synergy, antagonism, and indifference) may be explained by the mode of action of the different compounds of the EOs in combination with antibiotics. According to Rosato et al. [15], the mechanisms of action based on the synergism of gentamicin/EOs and in particular gentamicin/Pelargonium graveolens and gentamicin/Anibarosae odora are very difficult to elucidate. For this purpose, different hypotheses should be considered. All interactions between antimicrobial compounds can alter the effectiveness, and synergistic or antagonistic relationships may result in competition for possible primary targets. On the other hand, a synergistic multi-target effect could occur by involving enzymes, substrates, metabolites and proteins, receptors, ion channels, transport protein, ribosomes, DNA/RNA, and physicochemical mechanisms.

It also found that some antibiotics that are ineffective against $A$. baumannii show very interesting synergistic activities, which can be explained by the fact that the molecule contained in this antibiotic helps to lead the EO to its target. The action of tea tree EO did not cause either the leakage of potassium ions in P. aeruginosa or the release of absorbent molecules at $280 \mathrm{~nm}$.

For this, research focused on how the microorganism tolerates high concentrations of this oil and/or components. These studies showed that tolerance is associated with the external membrane. The treatment of $P$. aeruginosa with nonapeptide B polymixin or 
EDTA causes the permeabilization of the membrane. As a result, the cells become more susceptible to bactericidal effects of tea tree EO, terpinen-4-ol, and $\gamma$-terpinene [41,42].

\section{Materials and Methods}

\subsection{Plant Material and Isolation of EOs}

Samples were collected in the north-eastern part of Algeria, in the Bordj-Mira city (M. pulegium L.) $\left(36^{\circ} 33^{\prime} 52.9^{\prime \prime} \mathrm{N} ; 5^{\circ} 17^{\prime} 11.7^{\prime \prime} \mathrm{E}\right)$ and in the city of Semaoun (Artemisia herba alba Asso.) ( $\left.36^{\circ} 35^{\prime} 54.82^{\prime \prime} \mathrm{N} ; 4^{\circ} 50^{\prime} 01.48^{\prime \prime} \mathrm{E}\right)$ in the district of Bejaia. The taxonomic identity of the plants was performed by Professor BEKDOUCHE F. (Batna 2 University, Algeria) by comparing voucher specimens with those of known identity already deposited in the herbarium of the Department of Botany, National Institute of Agronomy, Algeria. Aerial parts were dried at room temperature for 15 days.

Dried aerial parts were subjected to hydrodistillation for $3 \mathrm{~h}$ using a Clevenger-type apparatus. The EOs were collected after decantation, dried over anhydrous sodium sulfate to remove residual water and stored in sealed dark glass vials at $4{ }^{\circ} \mathrm{C}$ until used. The oil yields were $1.9 \%$ and $0.7 \%$ ( $w / w$ from the dried material) for M. pulegium and A. herba alba, respectively.

\subsection{Gas Chromatography-Flame Ionization Detector (GS-FID) and Gas Chromatography-Mass Spectrometry (GC-MS) Analysis}

An Agilent technologies 7890A gas chromatograph equipped with an FID was used for compound separations with an HP5 capillary column $(30 \mathrm{~m} \times 0.32 \mathrm{~mm}$ i.d., $0.40 \mu \mathrm{m}$ phase thickness). The oven temperature program was as follows: first 2 min at $80^{\circ} \mathrm{C}$, then from 80 to $200{ }^{\circ} \mathrm{C}$ with an increasing rate of $5^{\circ} \mathrm{C} / \mathrm{min}$, then $5 \mathrm{~min}$ at $200^{\circ} \mathrm{C}$, then from 200 to $260^{\circ} \mathrm{C}$ with an increasing rate of $20^{\circ} \mathrm{C} / \mathrm{min}$, and finally held at the final temperature for $5 \mathrm{~min}$. The detector and inlet temperatures were $280^{\circ} \mathrm{C}$. Hydrogen was used as a carrier gas at a constant flow rate of $1 \mathrm{~mL} / \mathrm{min}$ with a split ratio of $70 / 1$. The injections were $1 \mu \mathrm{L}$ of $\mathrm{EO}$ in methylene chloride $\left(50 \mathrm{mg}\right.$ of $\mathrm{EO}$ in $1 \mathrm{~mL} \mathrm{CH}_{2} \mathrm{Cl}_{2}$ ).

The GC-MS analyses were performed using an Agilent technologies 7890A gas chromatograph equipped with an HP5MScapillary column $(30 \mathrm{~m}, 0.25 \mathrm{~mm}, 0.25 \mu \mathrm{m})$, and a mass detector MS 5975C VL MSD was operated in the EI mode. Helium was used as a carrier gas at a flow rate of $1 \mathrm{~mL} / \mathrm{min}$ with a split ratio of 50/1. The oven temperature program was as follows: first $2 \mathrm{~min}$ at $80^{\circ} \mathrm{C}$, then from 80 to $200^{\circ} \mathrm{C}$ with an increasing rate of $5{ }^{\circ} \mathrm{C} / \mathrm{min}$, then $5 \mathrm{~min}$ at $200{ }^{\circ} \mathrm{C}$, then from 200 to $260^{\circ} \mathrm{C}$ with an increasing rate of $20^{\circ} \mathrm{C} / \mathrm{min}$, and finally held at the final temperature for $5 \mathrm{~min}$. The detector and inlet temperatures were $280^{\circ} \mathrm{C}$. The identification of components was based on the comparison of their mass spectra with those of WILEY and NIST Libraries as well as on the comparison of their retention indices of the authentic standard with the literature [43].

\subsection{Tested Bacterial Isolates}

In this study, six bacterial strains were used. The bacterial cells assayed included three Gram-positive bacteria, i.e., Listeria innocua CLIP 74915, S. aureus ATCC25922, and methicillin-resistant S. aureus strain S19 (MRSA S19) (ST80-MRSA-IVk, PVL+) recovered from pus), and three Gram-negative bacteria, i.e., E. coli ATCC25922, Pseudomonas aeruginosa ATCC27853, and Imipenem-resistant Acinetobacter baumannii strain 3310 (IRAB S3310) isolated from the catheter, producing OXA-23 enzyme and resistant to cefotaxime (CTX) and cefepime (FEP). The bacterial strains were stored at $4{ }^{\circ} \mathrm{C}$ in a nutrient broth for the Gram-negative bacteria and in a brain heart infusion broth for the Gram-positive bacteria. Fresh cultures were prepared on a Mueller-Hinton Agar at $37^{\circ} \mathrm{C}$ for $24 \mathrm{~h}$.

\subsection{Study of the Antibacterial Activities of EOs in Solid Media}

The antibacterial activities of the EOs were tested according to the aromatogram method. 
After the inoculation of the bacterial strain (load of $10^{8}$ Colony forming Unit (CFU) $/ \mathrm{mL}$ ), discs of Whatman No. 1 paper ( $6 \mathrm{~mm}$ in diameter) were deposited on an Mueller-Hinton Agar. Subsequently, $10 \mu \mathrm{L}$ of each EO were placed on each disc. After incubation at $37^{\circ} \mathrm{C}$ for $24 \mathrm{~h}$, the diameters of the inhibition zones around the discs were measured. The tests were performed in triplicate, and the result was expressed as the mean of the three tests results \pm standard deviation [13].

\subsection{Study of the Antibacterial Activities of EOs in a Liquid Medium}

The MICs of the EOs were determined using the Mueller-Hinton broth micro-dilution method [44]. The ranges of the EOs between 0.3 and 300 were performed in a 96-well round-bottomed microplate. All the tests were performed with an Mueller-Hinton broth added by tween $80(0.5 \%)$ at a rate of $100 \mu \mathrm{L}$ per well. Finally, each well was inoculated with $100 \mu \mathrm{L}$ of the bacterial suspension (final load in each well is $5 \times 10^{5} \mathrm{CFU} / \mathrm{mL}$ ). After $24 \mathrm{~h}$ incubation at $37^{\circ} \mathrm{C}$, the MIC corresponded to the EO concentration of the first well showing no bacterial growth.

\subsection{Screening the Synergistic Effect of the EO with Antibiotic Discs}

The standard antibiotics used in this study included different groups of antibiotics: AK, NA, AT, CAZ, CIP, CTX, FEP, IMP, piperacillin (PIP), ticarcillin-clavulanic acid (TCC), ticarcillin (TIC), and TOB for IRAB S3310 and CX and OX for MRSA S19. The synergistic effect was tested according to the modified procedure of Boonyanugomol et al. [40]. The standard antibiotics discs were individually impregnated with $10 \mu \mathrm{L}$ of each EO and placed on agar plates containing Mueller-Hinton Agar inoculated with a bacterial suspension $\left(10^{8} \mathrm{CFU} / \mathrm{mL}\right)$. After incubation overnight, the zones of inhibition produced by the EOs combined with standard antibiotics were evaluated.

The data were interpreted as indifference, antagonism, and synergy by comparing the diameter of the inhibition zone in combination (EO + standard antibiotic) with the sum of the diameters of the inhibition zones of the two agents tested separately (EO and antibiotic).

\section{Conclusions}

The results of the screening of the associative effect of EOs of M. pulegium and A. herba alba with antibiotics in a solid medium showed that SARM S19 exhibited synergistic effects in association with CX with a better synergy in the case of M. pulegium EO. The result observed for the EOs with the different groups of antibiotics against the IRAB S3310 strain differed, depending on the EO and the antibiotic used (10 synergistic combinations, 12 antagonistic combinations, and two indifferent combinations). However, the strongest activity was observed for M. pulegium EO in combination with AK.

These preliminary results are promising in expanding the therapeutic arsenal of plants with antibacterial properties. Their screenings allow the discovery of new antibacterials, which may constitute an alternative to the use of conventional antibiotics that have become ineffective.

The results showed that EOs combined with antibiotics can be very effective sources to help fight against multi-resistant bacteria. In addition, the antagonistic effects observed indicated that all combinations are not recommended.

Supplementary Materials: The following supporting information can be downloaded. Figure S1: Effect of the Mentha pulegium essential oil against bacterial strains; Figure S2: Effect of the Artemisia herba alba essential oil against bacterial strains; Figure S3: antibiogram showing the resistance of the strain IRAB S3310 against different antibiotics; Figure S4: Effect of the association of Mentha pulegium essential oil with amikacin (AK) and tobramicin (TOB) and Artemisia herba alba essential oil with cefotaxime (CTX) against IRAB S3310.

Author Contributions: Conceptualization, F.B.-H.; methodology, F.B.-H., I.B., F.D., S.B. and A.T.; formal analysis, F.B.-H. and I.B.; microbiology resources, F.D., S.B. and A.T.; plant resource, F.B.-H.; 
data curation, F.B.-H. and I.B.; writing-original draft preparation, F.B.-H.; writing-review and editing, F.B.-H., I.B., F.D., S.B. and A.T.; visualization, F.B.-H.; supervision, A.T. and I.B.; project administration, Jijel University, Bejaia University, and Aix Marseille University. All authors have read and agreed to the published version of the manuscript.

Funding: This research received no external funding.

Institutional Review Board Statement: No ethical clearance was needed in this study.

Informed Consent Statement: Not applicable.

Data Availability Statement: The study did not report any data.

Conflicts of Interest: The authors declare no conflict of interest.

Sample Availability: Samples of the compounds are not available from the authors.

\begin{tabular}{|c|c|}
\hline \multicolumn{2}{|c|}{ Abreviations } \\
\hline A. baumannii & Acinetobacter baumannii \\
\hline A. herba alba & Artemisia herba alba \\
\hline A & antagonism \\
\hline AK & amikacin \\
\hline AT & aztreonam \\
\hline CAZ & ceftazidime \\
\hline CIP & ciprofloxacin \\
\hline CTX & cefotaxime \\
\hline $\mathrm{CX}$ & cefoxitin \\
\hline E. coli & Escherichia coli \\
\hline EI & electronic impact \\
\hline $\mathrm{EO}$ & essential oil \\
\hline FEP & cefepime \\
\hline GC-FID & gas chromatography-flame ionization detector \\
\hline GC-MS & gas chromatography-mass spectrometry \\
\hline i.d. & internal diameter \\
\hline IMP & imipenem \\
\hline IZD & inhibition zone diameter \\
\hline L. innocua & Listeria innocua \\
\hline MIC & minimal inhibitory concentration \\
\hline M. pulegium & Mentha pulegium \\
\hline NA & nalidixic acid \\
\hline NZ & no inhibition Zone \\
\hline OX & oxacillin \\
\hline P. aeruginosa & Pseudomonas aeruginosa \\
\hline PIP & piperacillin \\
\hline S. aureus & Staphylococcus aureus \\
\hline$S$ & synergism \\
\hline TCC & ticarcillin-clavulanic acid \\
\hline TIC & ticarcillin \\
\hline TOB & tobramicin \\
\hline VAN & vancomycin \\
\hline
\end{tabular}

\section{References}

1. Cavallo, J.D.; Fabre, R.; Jehl, F.; Rapp, C.; Garrabé, E. Bêtalactamines. EMC-Mal. Infect. 2004, 1, 129-202.

2. Gordon, N.C.; Wareham, D.W. Multidrug-resistant Acinetobacter baumannii: Mechanisms of virulence and resistance. Int. J. Antimicrob. Agents 2010, 35, 219-226. [CrossRef] [PubMed]

3. Gavanji, S.; Mohammadi, E.; Larki, B.; Bakhtari, A. Antimicrobial and cytotoxic evaluation of some herbal essential oils in comparison with common antibiotics in bioassay condition. Integr. Med. Res. 2014, 3, 142-152. [CrossRef]

4. Dorman, H.J.D.; Deans, S.G. Antimicrobial agents from plants: Antibacterial activity of plant volatile oils. J. Appl. Microbiol. 2000, 88, 308-316. [CrossRef] [PubMed]

5. Sartoratto, A.; Machado, A.L.M.; Delarmelina, C.; Figueira, G.M.; Duarte, M.C.T.; Rehder, V.L.G. Composition and Antimicrobial Activity of Essential Oils from Aromatic Plants used in Brazil. Braz. J. Microbiol. 2004, 35, 275-280. [CrossRef] 
6. Mutlu-Ingok, A.; Devecioglu, D.; Dikmetas, D.-N.; Karbancioglu-Guler, F.; Capanoglu, E. Antibacterial, antifungal, antimycotoxigenic, and antioxidant activities of essential oils: An updated review. Molecules 2020, 25, 4711. [CrossRef]

7. Mahendran, G.; Verma, S.K.; Rahman, L.-U. The traditional uses, phytochemistry and pharmacology of spearmint (Mentha spicata L.): A review. J. Ethnopharmacol. 2021, 278, 114266. [CrossRef]

8. Tafrihi, M.; Imran, M.; Tufail, T.; Gondal, T.A.; Caruso, G.; Sharma, S.; Sharma, R.; Atanassova, M.; Atanassov, L.; Tsouh Fokou, P.V.; et al. The Wonderful Activities of the Genus Mentha: Not Only Antioxidant Properties. Molecules 2021, 26, 1118. [CrossRef] [PubMed]

9. Maiza-Benabdesselam, F.; Bekka, F.; Touati, A.; Gören, A.C.; Benallaoua, S. Antibacterial activity of essential oils of two algerian medicinal plants: Origanum glandulosum Desf. and Artemisia herba Alba Asso. Life Sci. Leafl. 2011, 16, 583-594.

10. Maiza-Benabdesselam, F.; Bekka, F.; Benallaoua, S.; Bougoffa, K. Antibacterial activity of essential oils of two algerian medicinal plants. 3rd Int. Conf. Drug Discov. Ther. Curr. Med. Chem. 2011, 18, SL-14.

11. Tohidpour, A.; Sattari, M.; Omidbaigi, R.; Yadegar, A.; Nazemi, J. Antibacterial effect of essential oils from two medicinal plants against Methicillin-resistant Staphylococcus aureus (MRSA). Phytomedicine 2010, 17, 142-145. [CrossRef] [PubMed]

12. Khadir, A.; Bendahou, M.; Benbelaid, F.; Bellahcene, C.; Abdelouahid, D.E.; Muselli, A.; Paollini, J.; Desjober, J.; Costa, J. Evaluation of the MRSA sensitivity to essential oils obtained from four Algerian medicinal plants. J. Appl. Pharm. Sci. 2013, 3 , 018-024.

13. Bekka-Hadji, F.; Bombarda, I.; Touati, A. Antibacterial activity against methicillin-resistant Staphylococcus aureus of five essential oils from Algerian medicinal plants (Lamiaceae). J. Essent. Oil Res. 2016, 28, 518-527. [CrossRef]

14. Cui, H.; Zhang, C.; Li, C.; Lin, L. Inhibition mechanism of cardamom essential oil on methicillin-resistant Staphylococcus aureus biofilm. Food Sci. Technol. 2020, 122, 109057. [CrossRef]

15. Rosato, A.; Piarulli, M.; Corbo, F.; Muraglia, M.; Carone, A.; Vitali, M.E.; Vitali, C. In Vitro Synergistic Action of Certain Combinations of Gentamicin and Essential Oils. Curr. Med. Chem. 2010, 17, 3289-3295. [CrossRef] [PubMed]

16. Zafar, A.; Shaukat, S.; Mahnaaz, K.H.; Arshiya, T.; Zahoor, A. Synergistic Effect of Salvadora persica Extracts, Tetracycline and Penicillin Against Staphylococcus aureus. Afr. J. Basic Appl. Sci. 2010, 2, 25-29.

17. Durate, A.; Silva, F.; Ferriera, S.; Domingues, F.C. Synergitic activity of coriander oil and conventional antibiotics against Acinetobacter baumannii. Phytomedecine 2012, 19, 236-238. [CrossRef] [PubMed]

18. Quezel, P.; Santa, S. Nouvelle Flore de l'Algérie et des Régions Désertiques Méridionales; Tome II C.N.R.S.: Paris, France, $1933 ;$ p. 603.

19. Mahboubi, M.; Haghi, G. Antimicrobial activity and chemical composition of Mentha pulegium L. essential oil. J. Ethnopharmacol. 2008, 119, 325-327. [CrossRef]

20. Hajlaoui, H.; Trabelsi, N.; Noumi, E.; Snoussi, M.; Fallah, H.; Ksouri, R.; Bakhrouf, A. Biological activities of the essential oils and methanol extract of tow cultivated mint species (Mentha longifolia and Mentha pulegium) used in the Tunisian folkloric medicine. World J. Microbiol. Biotechnol. 2009, 25, 2227-2238. [CrossRef]

21. Fenardji, F.; Klur, M.; Fourlon, C.; Ferrando, R. Contribution à l'étude de l'armoise blanche (Artemisia herba alba L.). RcvElevMédvét. Pays Trop. 1974, 27, 203-206. [CrossRef]

22. Salido, S.; Valenzuela, L.R.; Altarejos, J.; Nogueras, M.; Sánchez, A.; Cano, E. Composition and infraspecific variability of Artemisia herba-alba from southern Spain. Biochem. Syst. Ecol. 2004, 32, 265-277. [CrossRef]

23. Atoum, M.; Al-Charchafchi, F.; Modallal, N. Biological activity and antimutagencity of Water Soluble Phytotoxins from Artemisia herba alba Asso. Pak. J. Biol. Sci. 2006, 9, 1774-1778. [CrossRef]

24. Bendjilali, B.; Richard, H. Etude de quelquespeuplementsd'Armoise blanche du Maroc Artemisia herba-alba. Riv. Ital. EPPOS 1980 $62,69-74$.

25. Bendjilali, B.; Sarris, J.; Richard, H. Nouveaux Chemotypes d'Artemisiaherba alba. Sci. Aliment. 1982, $2,515-527$.

26. Vernin, G.; Merad, L.O. Mass spectra and Kovats indexes of some new cis-chrysanthenyl esters found in the essential oil of Artemisia herba alba from Algeria. J. Essent. Oil Res. 1994, 6, 437-448. [CrossRef]

27. Vernin, G.; Parkanyi, C. GC/MS analysis of Artemisia herba alba Asso. From Algeria, Non polar and polar extracts. Riv. Ital. EPPOS 2001, 32, 3-16.

28. Said, M.E.-A.; Vanloot, P.; Bombarda, I.; Naubron, J.V.; Dahmane, E.M.; Aamouche, H.; Jean, M.; Vanthuyne, N.; Dupuy, N.; Roussel, C. Analysis of the major chiral compounds of Artemisia herba-alba essential oils (EOs) using reconstructed vibrational circular dichroism (VCD) spectra: En route to a VCD chiral signature of EOs. Anal. Chim. Acta 2016, 903, 121-130. [CrossRef]

29. Ait-Ouazzou, A.; Lorán, S.; Arakrak, A.; Laglaoui, A.; Rota, C.; Herrera, A.; Pagán, R.; Conchello, P. Evaluation of the chemical composition and antimicrobial activity of Mentha pulegium, Juniperus phoenicea, and Cyperus longus essential oils from Morocco. Food Res. Int. 2012, 45, 313-319. [CrossRef]

30. Teixeira, B.; Marques, A.; Ramos, C.; Batista, I.; Serrano, C.; Matos, O.; Neng, N.R.; Nogueira, J.M.F.; Saraiva, J.A.; Nunes, M.L. European pennyroyal (Mentha pulegium) from Portugal: Chemical composition of essential oil and antioxidant and antimicrobial properties of extracts and essential oil. Ind. Crops Prod. 2012, 36, 81-87. [CrossRef]

31. Duru, M.E.; Öztürk, M.; Ugur, A.; Ceylan, Ö. The constituents of essential oil and in vitro antimicrobial activity of Micromeria cilicica from Turkey. J. Ethnopharmacol. 2004, 94, 43-48. [CrossRef]

32. Benouda, A.; Benjilali, B.; Hassar, M. Les Propriétés Antiseptiques des Huiles Essentielles ln Vitro. Testées Contre des Germes Pathogènes Hospitaliers. Phytotherapia 1988, 59, 115-119. 
33. Tepe, B.; Daferera, D.; Sökmen, M.; Polissiou, M.; Sökmen, A. The in vitro antioxidant and antimicrobial activities of the essential oil and various extracts of Origanum syriacum L. var bevanii. J. Sci. Food Agric. 2004, 84, 1389-1396. [CrossRef]

34. Fu, Y.J.; Zu, Y.G.; Chen, L.Y.; Shi, X.G.; Wang, Z.; Sun, S.; Efferth, T. Antimicrobial Activity of Clove and Rosemary Essential Oils Alone and in Combination. Phytother. Res. 2007, 21, 989-994. [CrossRef]

35. Rasooli, I.; Mirmostafa, S.A. Bacterial Susceptibility to and Chemical Composition of Essential Oils from Thymus kotschyanus and Thymus persicus. J. Agric. Food Chem. 2004, 51, 2200-2205. [CrossRef] [PubMed]

36. Uzair, B.; Niazl, N.; Bano, A.; Khan, B.A.; Zafar, N.; Iqbal, M.; Tahira, R.; Fasim, F. Essential oils showing in vitro antiMRSA and synergistic activity with penicillin group of antibiotics. Pak. J. Pharm. Sci. 2017, 30, 1997-2002. [PubMed]

37. Al-Samydai, A.M.J. Jordanian medicinal plants as an alternative source for new antimicrobials against multi drug resistant: Review. Int. J. Pharmacogn. 2018, 5, 581-589.

38. D'Arrigo, M.; Ginestra, G.; Mandalari, G.; Furneri, P.M.; Bisignano, G. Synergism and post antibiotic effect of tobramicin and Melaleuca alternifolia (teatree) oil against Staphylococcus aureus and Escherichia coli. Phytomedicine 2011, 17, 317-322. [CrossRef]

39. Halawani, E. Antibacterial Activity of Thymoquinone and Thymohydroquinone of Nigella sativa L. and Their Interaction with Some Antibiotics. Adv. Biol. Res. 2009, 3, 148-152.

40. Boonyanugomol, W.; Kraisriwattana, K.; Rukseree, K.; Boonsam, K.; Narachai, P. In vitro synergistic antibacterial activity of the essential oil from Zingiber cassumunar Roxb against extensively drug-resistant Acinetobacter baumannii strains. J. Infect. Public Health 2017, 10, 586-592. [CrossRef]

41. Cox, S.D.; Mann, C.M.; Markham, J.L. Interactions between components of the essential oil of Melaleuca alternifolia. J. Appl. Microbiol. 2001, 91, 492-497. [CrossRef]

42. Carson, C.F.; Hammer, K.A.; Riley, T.V. Melaleuca alternifolia (Tea Tree) Oil: A Review of Antimicrobial and Other Medicinal Properties. Clin. Microbiol. Rev. 2006, 19, 50-62. [CrossRef] [PubMed]

43. Adams, R.P. Identification of Essential Oil Components by Gas Chromatography/Mass Spectrometry, 4th ed.; Allured Publ. Corp.: Carol Stream, IL, USA, 2007.

44. Vardar-Ünlü, G.; Candan, F.; Sökmen, A.; Daferera, D.; Polissiou, M.; Sökmen, M.; Dönmez, E.; Tepe, B. Antimicrobial and Antioxidant Activity of the Essential Oil and Methanol Extracts of Thymus pectinatus Fisch. et Mey. Var. pectinatus (Lamiaceae). J. Agric. Food Chem. 2003, 51, 63-67. [CrossRef] [PubMed] 